\title{
Application of Exopolysaccharide-Producing Cultures in Reduced-Fat Cheddar Cheese: Composition and Proteolysis*
}

\author{
S. Awad, ${ }^{1} \dagger$ A. N. Hassan, ${ }^{1}$ and F. Halaweish ${ }^{2}$ \\ ${ }^{1}$ Minnesota-South Dakota Dairy Foods Research Center, Dairy Science Department, and \\ ${ }^{2}$ Department of Chemistry and Biochemistry, South Dakota State University, Brookings 57007
}

\begin{abstract}
Proteolysis during ripening of reduced fat Cheddar cheeses made with different exopolysaccharide (EPS)producing and nonproducing cultures was studied. A ropy strain of Lactococcus lactis ssp. cremoris (JFR1) and capsule-forming nonropy and moderately ropy strains of Streptococcus thermophilus were used in making reduced-fat Cheddar cheese. Commercial Cheddar starter was used in making full-fat cheese. Results showed that the actual yield of cheese made with JFR1 was higher than that of all other reducedfat cheeses. Cheese made with JFR1 contained higher moisture, moisture in the nonfat substance, and residual coagulant activity than all other reduced-fat cheeses. Proteolysis, as determined by PAGE and the level of water-soluble nitrogen, was also higher in cheese made with JFR1 than in all other cheeses. The HPLC analysis showed a significant increase in hydrophobic peptides (causing bitterness) during storage of cheese made with JFR1. Cheese made with the capsule-forming nonropy adjunct of $S$. thermophilus, which contained lower moisture and moisture in the nonfat substance levels and lower chymosin activity than did cheese made with JFR1, accumulated less hydrophobic peptides. In conclusion, some EPS-producing cultures produced reduced-fat Cheddar cheese with moisture in the nonfat substance similar to that in its full-fat counterpart without the need for modifying the standard cheese-making protocol. Such cultures might accumulate hydrophobic (bitter) peptides if they do not contain the system able to hydrolyze them. For making high quality reduced-fat Cheddar
\end{abstract}

Received May 1, 2005.

Accepted July 18, 2005.

Corresponding author: Ashraf N. Hassan; e-mail: Ashraf.Hassan @sdstate.edu.

*Published with the approval of the director of the South Dakota Agricultural Experiment Station as Publication Number 3485 of the Journal Series. This research was supported in part by MinnesotaSouth Dakota Dairy Foods Research Center, Brookings, SD, and Midwest Dairy Association, St. Paul, MN.

$\dagger$ Current address: Department of Dairy Science and Technology, Faculty of Agriculture, Alexandria University, Egypt. cheese, EPS-producing cultures should be used in conjunction with debittering strains.

(Key words: reduced-fat Cheddar cheese, proteolysis, exopolysaccharide-producing cultures)

Abbreviation key: EPS = exopolysaccharide, FFC = full-fat control cheese, MNFS = moisture in the nonfat substance, RF-3534 = reduced-fat cheese made with the moderate ropy strain Streptococcus thermophilus CHCC 3534, RF-5842 = reduced-fat cheese made with the EPS-negative genetic variant Streptococcus thermophilus CHCC 5842, RFC = reduced-fat control cheese, RF-JFR1 = reduced-fat cheese made with the ropy culture Lactococcus lactis ssp. cremoris JFR1, RF-Slab = reduced-fat cheese made with the capsuleforming nonropy strain Streptococcus thermophilus Slab, WSN = water-soluble nitrogen.

\section{INTRODUCTION}

Proteolysis during ripening plays a major role in the development of cheese texture and flavor. A wellbalanced breakdown of casein into small peptides and amino acids is necessary for the development of an acceptable Cheddar cheese flavor (Singh et al., 2003). These products contribute directly to flavor (Visser, 1993) or act as precursors for the production of flavor components.

Low- and reduced-fat cheeses are gaining popularity due to consumer awareness of the health benefits of low-fat diets. Low-fat cheeses typically have poor body, flavor, and functional properties (Mistry, 2001). The firm/rubbery texture of low-fat cheeses is due to the inadequate breakdown of casein (Mistry and Kasperson, 1998). To overcome rigidity in reduced-fat cheese, moisture level is increased by lowering cooking temperatures or draining whey at higher $\mathrm{pH}$. However, such conditions result in a lower retention of chymosin and a negative influence on both flavor and texture of cheese (Mistry, 2001).

Exopolysaccharide (EPS)-producing cultures have been used in making fermented dairy products to improve their rheological properties, prevent syneresis, and replace stabilizers (Hassan et al., 1996; Adapa 
and Schmidt, 1998; Broadbent et al., 2003; Hassan et al., 2004). In addition, these cultures increase water retention and improve melting properties of low-fat Mozzarella cheese (Perry et al., 1998; Broadbent et al., 2003). In a current research project, several EPSproducing cultures have been used in making reducedfat Cheddar cheese. These cultures produced reducedfat cheese with physical characteristics similar to those of its full-fat counterpart (Awad et al., 2005). However, cheese made with some EPS-producing cultures developed bitterness after a few months of ripening. The objective of this work was to monitor proteolysis during ripening of reduced-fat Cheddar cheeses made with different EPS-producing and nonproducing cultures and to study relationships among moisture levels, chymosin activity, production of free amino acids, and accumulation of bitter peptides.

\section{MATERIALS AND METHODS}

\section{Cultures}

An EPS-producing moderate ropy Streptococcus thermophilus CHCC 3534 and its EPS-negative genetic variant Streptococcus thermophilus CHCC 5842 (Chr. Hansen, Hørsholm, Denmark), a capsule-forming nonropy Streptococcus thermophilus (Slab; Hassan et al., 1995), and a ropy Lactococcus lactic spp. cremoris (JFR1; Hassan et al., 2003) were used in this study. None of the EPS-producing cultures used in this study increased the viscosity of Cheddar cheese whey (data not shown). All strains were maintained at $-80^{\circ} \mathrm{C}$ in $11 \%$ sterile reconstituted skim milk supplemented with $20 \%$ ( $\mathrm{vol} / \mathrm{vol}$ ) glycerol. Lactococci and streptococci were grown in M17 broth (Becton Dickinson and Co., Sparks, MD), supplemented with $0.5 \%$ (wt/vol) lactose and incubated overnight at $32^{\circ} \mathrm{C}$ (for lactococci) or $39^{\circ} \mathrm{C}$ (for streptococci). Each strain was subcultured ( $1 \% \mathrm{vol} / \mathrm{vol}) 3$ times and then transferred to $11 \%$ reconstituted skim milk for overnight incubation to produce the cheese starter culture. Commercial direct to vat set Cheddar culture (DVS 850) was obtained from Chr. Hansen (Milwaukee, WI).

\section{Cheese Making}

Raw milk was obtained from the Dairy Research and Training Facility at South Dakota State University. Three replicates of Cheddar cheese were manufactured from standardized (reduced-fat, $2 \%$ or full-fat, $3.6 \%$ ) pasteurized milk (heated to $63^{\circ} \mathrm{C}$ for $30 \mathrm{~min}$ and cooled to $31^{\circ} \mathrm{C}$ ). Cheese milk ( $100 \mathrm{~kg}$ ) was assigned to 2 double-O cheese vats (Kusel Equipment Co., Watertown, WI). The following 6 treatments of cheese were made: 1$)$ FFC = full-fat cheese made using the com- mercial Cheddar starter culture (DVS 850;0.015\% wt/ wt); 2) $\mathbf{R F C}=$ reduced-fat cheese made using the commercial Cheddar starter culture (DVS 850;0.015\% wt/ wt); 3) RF-JFR1 = reduced-fat cheese made with the ropy strain Lactococcus lactis spp. cremoris JFR1 (2\% vol/wt); 4) RF-Slab = reduced-fat cheese made with a capsule-forming nonropy Streptococcus thermophilus $(0.4 \% \mathrm{vol} / \mathrm{wt}) \mathrm{plus}$ the commercial culture $(0.011 \% \mathrm{wt} /$ wt); 5) RF-3534 = reduced-fat cheese made with EPSproducing Streptococcus thermophilus CHCC 3534 $(0.4 \% \mathrm{vol} / \mathrm{wt})$ plus the commercial culture $(0.011 \% \mathrm{wt} /$ wt); and 6) RF-5842 = reduced-fat cheese made with the EPS-negative genetic variant of $\mathrm{CHCC} 3534$ (Streptococcus thermophilus CHCC 5842; 0.4\% vol/wt) plus the commercial culture $(0.011 \% \mathrm{wt} / \mathrm{wt})$. The inoculum size was selected, based on the preliminary experiment data, to give the same acidification rate and cheese making time $(5 \mathrm{~h})$ in all treatments.

Cultures were added at $31^{\circ} \mathrm{C}$ to milk that was then ripened for $1 \mathrm{~h}$. A $0.01 \%$ (vol/wt) chymosin (Chymax, Chr. Hansen) was added to clot milk in $30 \mathrm{~min}$. The coagulum was cut and cooked to $39^{\circ} \mathrm{C}$ over $30 \mathrm{~min}$ and held at this temperature for 30 more minutes. After whey drainage, the curd was cheddared and then milled when the $\mathrm{pH}$ reached 5.4. Curd was salted at $1.7 \%$ in 3 equal applications over $15 \mathrm{~min}$. The curd was hooped in rectangular blocks, pressed overnight at $2.5 \mathrm{~kg} / \mathrm{cm}^{2}$, vacuum-packed, and ripened at $4^{\circ} \mathrm{C}$ for $6 \mathrm{mo}$.

\section{Chemical Composition of Cheese}

Cheese ( $1 \mathrm{~d}$ old) was analyzed for moisture by the oven method (method 926.08; AOAC, 2003), salt by chloride analyzer (model 926, Nelson Jameson Inc., Marshfield, WI), fat by Mojonnier (method 933.05; AOAC, 2003), and total protein by macro-Kjeldahl (method 920.123; AOAC, 2003). The $\mathrm{pH}$ was measured in a slurry prepared by macerating $20 \mathrm{~g}$ of grated cheese in $20 \mathrm{~mL}$ of deionized water.

Cheese yield was expressed as the ratio mass between the curd obtained after pressing stage and the weight of milk.

\section{Microbiological Analyses}

Cheese samples (10 g) were homogenized for $4 \mathrm{~min}$ with $90 \mathrm{~mL}$ of a sterile $2 \%$ sodium citrate solution in a laboratory blender 80 Stomacher (Seward 400, London, UK) and serially diluted using sterile $0.05 \%$ peptone. Appropriate dilutions were plated on lactose M17 agar. Duplicate dishes were incubated at 25 or $45^{\circ} \mathrm{C}$ for enumeration of lactococci and streptococci, respectively. 


\section{Determination of Residual Chymosin Activity}

The residual coagulant activity was determined by the method described by Hurley et al. (1999) with some modifications. The HPLC analysis was conducted using a Varian Prostar composed of 2 Prostar pumps and photo diode array detector. The peptides resulting from hydrolysis of the substrate by chymosin were separated on an RP-C18-Lichrospher analytical column $(250 \times 4.6 \mathrm{~mm}, 5 \mu \mathrm{m}$; Perkin Elmer, Norwalk, CT) equilibrated with solvent A $(0.1 \%$ trifluoroacetic acid in water) and solvent $\mathrm{B}(0.1 \%$ trifluoroacetic acid in acetonitrile). A gradient was generated by increasing the concentration of solvent B as follows: 15 to $50 \%$ solvent B over $20 \mathrm{~min}, 50 \%$ solvent B for $5 \mathrm{~min}, 50$ to $95 \%$ solvent B over 3 min, maintaining at $95 \%$ solvent $\mathrm{B}$ for $2 \mathrm{~min}$, and finally returning to equilibration conditions over $3 \mathrm{~min}$. The flow rate was $1 \mathrm{~mL} / \mathrm{min}$. The photo diode array detector was used to monitor analyses at $300 \mathrm{~nm}$. Integration of HPLC spectra was achieved using Star Software (Varian Chromatography Systems, Walnut Creek, CA). The concentration of residual coagulant activity was expressed as rennet activity units per kilogram of cheese using a standard curve of chymosin activity.

\section{Proteolysis Assessments}

Water-soluble nitrogen and free amino acids determination. Water-soluble nitrogen (WSN) in the fat-free cheese homogenates was determined according to the method developed by Kuchroo and Fox (1982). Free amino groups were measured using the cadmium-ninhydrin method described by Folkertsma and Fox (1992).

\section{Gel Electrophoresis Analysis}

Urea-PAGE was conducted on whole cheese samples using a Protean II vertical slab gel unit (BioRad Laboratories, Hercules, CA) as described by Andrews (1983). Bands were scanned and quantified using a computerized densitometer and Image Quant 3.3 software (GE Healthcare, Sunnyvale, CA).

\section{Reverse Phase-HPLC Analysis}

The profile of peptides in water-soluble extract (Kuchroo and Fox, 1982) were separated using the C18-Lichrospher analytical column $(250 \times 4.6 \mathrm{~mm}, 5$ $\mu \mathrm{m}$; Perkin Elmer). Samples were eluted with a 4-step linear gradient over a period of 75 min according to Awad et al. (1999). Separation was conducted at $21^{\circ} \mathrm{C}$ and peptides were monitored at 214 and $280 \mathrm{~nm}$. The areas of the chromatograms were divided into 2 re- gions according to the peptide elution time: hydrophilic peptides (retention time $<35 \mathrm{~min}$ ) and hydrophobic peptides (retention time $>35 \mathrm{~min}$ ). These peak areas of the different regions were statistically analyzed to evaluate the influence of the EPS-producing cultures on the relative amounts of peptides.

\section{Statistical Analyses}

Data reported are the average of 3 measurements per replicate. Cheeses were made 3 times. The SAS statistical analysis software package (SAS Institute, 1999) was used for ANOVA using the GLM procedure. Differences were considered significant at $P<0.05$.

\section{RESULTS AND DISCUSSION}

\section{Cheese Composition}

The composition of Cheddar cheese made with EPSproducing and nonproducing cultures is summarized in Table 1. In agreement with previous findings (Fenelon and Guinee, 1999; Guinee et al., 2000), decreasing the fat content of cheese milk resulted in an increase in cheese moisture and protein and a decrease in cheese yield, level of fat in DM, moisture in the nonfat substance (MNFS), and salt-in-moisture. Cheese made with the EPS-producing culture JFR1 had higher ( $P$ $<0.05)$ moisture and yield than did all other reducedfat cheeses. Cheese made with the capsule-forming nonropy culture (Slab) had higher $(P<0.05)$ moisture and yield than those made with the moderately ropy culture of S. thermophilus (RF-3534) and its EPS-negative variant (RF-5842). The yield of RF-JFR1 was 7.8\% higher than that of cheeses made with the EPSnonproducing culture (RF-5842). Fat in DM was similar $(P>0.05)$ among all reduced-fat cheeses. The MNFS was higher $(P<0.05)$ in RF-JFR1 than in all other reduced-fat cheeses. It is always the objective of the cheese manufacturer to produce reduced-fat cheese with similar MNFS to that of the full-fat counterpart. This requires modifications in cheese-making protocol that are always associated with textural and flavor defects. Interestingly, the use of JFR1 produced reduced-fat cheese with similar MNFS to that of the fullfat type without the need for modifying the cheesemaking procedure used in making the full-fat type.

No significant differences in $\mathrm{pH}$ were found among all cheeses after $1 \mathrm{~d}$ of manufacture (Figure 1). A drop in $\mathrm{pH}$ of all cheeses was observed during the first month of ripening. The relatively high MNFS in FFC and RF-JFR1 might have induced excessive growth of starter organisms, resulting in the most significant reduction in $\mathrm{pH}$. Under our cheese-making conditions, viscosity of the whey was not affected by using the 
Table 1. Chemical composition (\%), actual yield, and residual coagulant activity of full-fat and reduced-fat Cheddar cheese.

\begin{tabular}{lllllllllll}
\hline & \multicolumn{10}{c}{ Composition $^{1}$} \\
\cline { 2 - 10 } Treatment $^{2}$ & Protein & Fat & Moisture & Yield & Salt & Fat in DM & SM & MNFS & RCA & $\begin{array}{l}\text { RCA/g of } \\
\text { protein }\end{array}$ \\
\hline FFC & $25.1^{\mathrm{c}}$ & $32.1^{\mathrm{a}}$ & $39.7^{\mathrm{d}}$ & $10.4^{\mathrm{a}}$ & $1.5^{\mathrm{a}}$ & $53.2^{\mathrm{a}}$ & $3.7^{\mathrm{a}}$ & $58.5^{\mathrm{a}}$ & $18.4^{\mathrm{d}}$ & $0.07^{\mathrm{b}}$ \\
RFC & $32.2^{\mathrm{a}}$ & $20.2^{\mathrm{b}}$ & $42.6^{\mathrm{c}}$ & $8.5^{\mathrm{d}}$ & $1.4^{\mathrm{a}}$ & $35.2^{\mathrm{b}}$ & $3.4^{\mathrm{b}}$ & $53.4^{\mathrm{c}}$ & $20.2^{\mathrm{c}}$ & $0.06^{\mathrm{b}}$ \\
RF-JFR1 & $28.5^{\mathrm{b}}$ & $18.9^{\mathrm{c}}$ & $47.3^{\mathrm{a}}$ & $9.1^{\mathrm{b}}$ & $1.5^{\mathrm{a}}$ & $35.9^{\mathrm{b}}$ & $3.1^{\mathrm{c}}$ & $58.4^{\mathrm{a}}$ & $25.5^{\mathrm{a}}$ & $0.09^{\mathrm{a}}$ \\
RF-Slab & $30.5^{\mathrm{a}}$ & $19.9^{\mathrm{b}}$ & $44.0^{\mathrm{b}}$ & $8.8^{\mathrm{c}}$ & $1.4^{\mathrm{a}}$ & $35.5^{\mathrm{b}}$ & $3.3^{\mathrm{b}}$ & $54.9^{\mathrm{b}}$ & $21.5^{\mathrm{b}}$ & $0.07^{\mathrm{b}}$ \\
RF-3534 & $30.9^{\mathrm{a}}$ & $20.1^{\mathrm{b}}$ & $43.4^{\mathrm{c}}$ & $8.6^{\mathrm{d}}$ & $1.5^{\mathrm{a}}$ & $35.5^{\mathrm{b}}$ & $3.4^{\mathrm{b}}$ & $54.3^{\mathrm{bc}}$ & $20.5^{\mathrm{bc}}$ & $0.07^{\mathrm{b}}$ \\
RF-5842 & $32.3^{\mathrm{a}}$ & $20.0^{\mathrm{b}}$ & $42.7^{\mathrm{c}}$ & $8.5^{\mathrm{d}}$ & $1.4^{\mathrm{a}}$ & $35.0^{\mathrm{b}}$ & $3.3^{\mathrm{b}}$ & $53.4^{\mathrm{c}}$ & $20.2^{\mathrm{c}}$ & $0.06^{\mathrm{b}}$ \\
\hline
\end{tabular}

${ }^{\mathrm{a}-\mathrm{d}}$ Means within the same column with different subscriptions are significantly different $(P<0.05)$.

${ }^{1} \mathrm{SM}=$ Salt-in-moisture, MNFS = moisture in nonfat substance, $\mathrm{RCA}=$ residual coagulant activity, rennet activity units/kg of cheese.

${ }^{2} \mathrm{FFC}=$ Full-fat control; RFC = reduced-fat control; RF-JFR1 = reduced-fat cheese made with the ropy culture Lactococcus lactis ssp. cremoris JFR1; RF-Slab = reduced-fat cheese made with the capsule-forming nonropy strain Streptococcus thermophilus Slab; RF-3534 = reduced-fat cheese made with the moderate ropy strain Streptococcus thermophilus CHCC 3534; and RF-5842 = reduced-fat cheese made with the exopolysaccharide-negative genetic variant Streptococcus thermophilus CHCC 5842.

ropy culture JFR1. Preliminary experiments showed that ropiness produced by JFR1 increased as the growth temperature decreased. The cooking temperature used in this study $\left(39^{\circ} \mathrm{C}\right)$ was much higher than the optimum temperature for production of ropiness (around $28^{\circ} \mathrm{C}$ ). This might explain why the viscosity of the whey was slightly increased when Cheddar cheese curd was cooked at a relatively lower temperature $\left(35^{\circ} \mathrm{C}\right.$; Dabour et al., 2005).

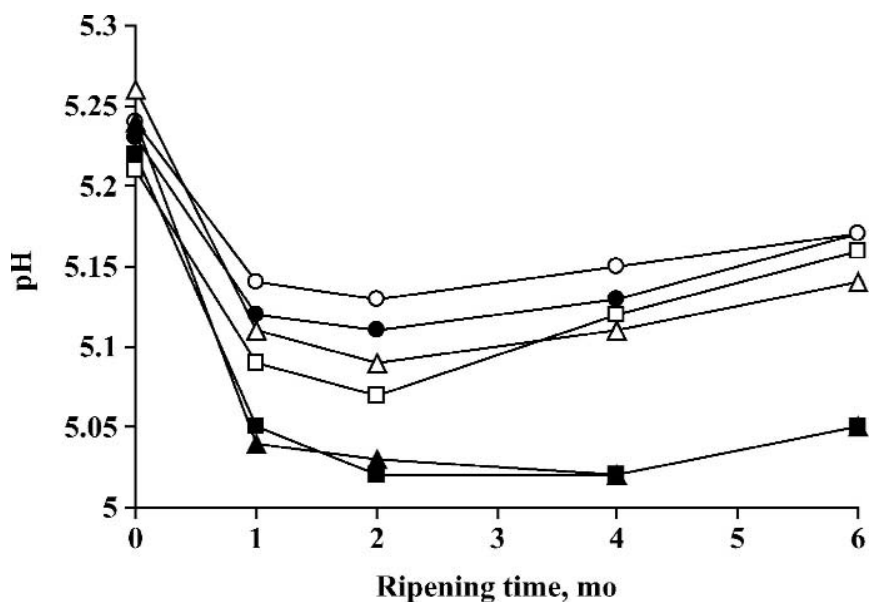

Figure 1. Changes in $\mathrm{pH}$ of full-fat and reduced-fat Cheddar cheeses during ripening. $\mathbf{\Delta}=\mathrm{FFC}$ (Full-fat control); $\triangle=\mathrm{RFC}$ (reduced-fat control); $\mathbf{\square}$ = RF-JFR1 (reduced-fat cheese made with the ropy culture Lactococcus lactis ssp. cremoris JFR1); $\square=$ RF-Slab (reduced-fat cheese made with the capsule-forming nonropy strain Streptococcus thermophilus Slab); 0 RF-3534 (reduced-fat cheese made with the moderate ropy strain Streptococcus thermophilus CHCC 3534); and $\bigcirc=$ RF-5842 (reduced-fat cheese made with the exopolysaccharide-negative genetic variant Streptococcus thermophilus CHCC 5842).

\section{Residual Chymosin Activity}

The residual chymosin activity in cheeses at $d 1$ of manufacture is given in Table 1 . The activity was 18.4 rennet activity units/kg in full-fat Cheddar cheese and was in the range (11.1 to 20.1) found by Hurley et al. (1999) in commercial Cheddar cheese. The chymosin activity in reduced-fat Cheddar cheeses ranged from 20.2 to 25.5 rennet activity units/kg, which was significantly higher than that found in the full-fat type. The amount of coagulant retained in cheese depends on several factors, such as the $\mathrm{pH}$ of curd at cutting and whey drainage, cooking temperature, and final moisture content of cheese (Fox and McSweeney, 1996). Because the same procedure was used in making reduced- and full-fat cheeses and there were no significant differences in the amount of rennet used or the $\mathrm{pH}$ at $\mathrm{d} 1$ of manufacture among all treatments, the differences in residual chymosin activity could be related only to differences in the moisture level.

\section{Viability of Starter in Cheese During Ripening}

The mean population of starter cultures is shown in Table 2. Numbers of mesophilic bacteria at $d 1$ of manufacture were similar $(P>0.05)$ in all cheeses. However, after 1 and 2 mo of ripening, counts of lactococci were higher in RF-JFR1 than in all other cheeses. The high moisture and low salt-in-moisture in RFJFR1 might have increased survival of lactococci during the first $60 \mathrm{~d}$ of ripening. A gradual decline in numbers of lactococci was seen after $60 \mathrm{~d}$ of ripening in all cheeses, resulting in about a 2-log reduction after 6 mo. The results were in agreement with those reported by Sallami et al. (2004), who found a decline 
Table 4. Levels of free amino group (mg of leucine/g of cheese) in full-fat and reduced-fat Cheddar cheeses during ripening. ${ }^{1}$

\begin{tabular}{llllll}
\hline & \multicolumn{5}{c}{ Ripening time, d } \\
\cline { 2 - 6 } Treatment & 1 & 30 & 60 & 120 & 180 \\
\hline FFC & $0.71^{\mathrm{b}, \mathrm{E}}$ & $0.98^{\mathrm{b}, \mathrm{D}}$ & $2.01^{\mathrm{a}, \mathrm{C}}$ & $2.65^{\mathrm{b}, \mathrm{B}}$ & $3.59^{\mathrm{b}, \mathrm{A}}$ \\
RFC & $0.74^{\mathrm{ab}, \mathrm{E}}$ & $1.21^{\mathrm{a}, \mathrm{D}}$ & $2.13^{\mathrm{a}, \mathrm{C}}$ & $2.80^{\mathrm{b}, \mathrm{B}}$ & $3.66^{\mathrm{b}, \mathrm{A}}$ \\
RF-JFR1 & $0.58^{\mathrm{c}, \mathrm{E}}$ & $0.68^{\mathrm{c}, \mathrm{D}}$ & $0.83^{\mathrm{c}, \mathrm{C}}$ & $1.22^{\mathrm{c}, \mathrm{B}}$ & $1.64^{\mathrm{c}, \mathrm{A}}$ \\
RF-Slab & $0.77^{\mathrm{a}, \mathrm{E}}$ & $1.19^{\mathrm{a}, \mathrm{D}}$ & $2.08^{\mathrm{a}, \mathrm{C}}$ & $3.06^{\mathrm{a}, \mathrm{B}}$ & $3.89^{\mathrm{a}, \mathrm{A}}$ \\
RF-3534 & $0.70^{\mathrm{b}, \mathrm{E}}$ & $0.99^{\mathrm{b}, \mathrm{D}}$ & $1.87^{\mathrm{b}, \mathrm{C}}$ & $2.66^{\mathrm{b}, \mathrm{B}}$ & $3.57^{\mathrm{b}, \mathrm{A}}$ \\
RF-5842 & $0.67^{\mathrm{b}, \mathrm{E}}$ & $0.83^{\mathrm{b}, \mathrm{D}}$ & $1.65^{\mathrm{b}, \mathrm{C}}$ & $2.49^{\mathrm{b}, \mathrm{B}}$ & $3.48^{\mathrm{b}, \mathrm{A}}$ \\
\hline
\end{tabular}

${ }^{\mathrm{a}, \mathrm{b}, \mathrm{c}}$ Means within the same column with different subscriptions are significantly different $(P<0.05)$.

${ }^{\mathrm{A}-\mathrm{E}}$ Means within the same row with different subscriptions are significantly different $(P<0.05)$.

${ }^{1} \mathrm{FFC}=$ Full-fat control; RFC = reduced-fat control; RF-JFR1 = reduced-fat cheese made with the ropy culture Lactococcus lactis ssp. cremoris JFR1; RF-Slab = reduced-fat cheese made with the capsuleforming nonropy strain Streptococcus thermophilus Slab; RF-3534 = reduced-fat cheese made with the moderate ropy strain Streptococcus thermophilus CHCC 3534; and RF-5842 = reduced-fat cheese made with the exopolysaccharide-negative genetic variant Streptococcus thermophilus CHCC 5842.

weight of cheese protein. Urea-PAGE was followed by densitometry analysis to quantify the degradation of $\alpha_{\mathrm{S} 1}$ - and $\beta$-caseins. The values of individual casein fractions were expressed as a percentage of the values of the corresponding casein in the same cheese at $\mathrm{d} 1$. The relative proportions of the residual $\beta$ - and $\alpha_{\mathrm{S}^{-}}$ caseins and the level of $\alpha_{\mathrm{S1}}$-1-casein as a percentage of the corresponding $\alpha_{\mathrm{S} 1}$-caseins at $\mathrm{d} 1$ are shown in Table 5. Generally, the trend observed with ureaPAGE was consistent with that for WSN data, with the overall level of proteolysis in RF-JFR1 being higher than in all other cheeses. The $\alpha_{\mathrm{S} 1}$-casein was hydrolyzed more extensively than $\beta$-casein during ripening. After 6 mo of ripening, the $\alpha_{\mathrm{S} 1}$-casein was almost completely degraded in all cheeses. The intensity of the band corresponding to $\beta$-casein decreased slightly throughout ripening with a concomitant increase in the bands corresponding to the $\gamma$-caseins (data not shown). Cheese RF-JRF1 showed the most significant reduction in the level of $\beta$-casein (Table 5). Peptides produced by chymosin action on $\beta$-casein have been widely reported as the major cause of bitterness in cheeses (Lemieux and Simard, 1992; Broadbent et al., 1998). No differences in the levels of $\gamma$-caseins were found among all cheeses (data not shown).

The level of $\alpha_{\mathrm{S}^{-1}}-1$ casein (f24-199) during the 2 mo of ripening was higher in RF-JFR1 than in all other cheeses, which could be due to its higher residual chymosin activity and moisture content. The concentration of $\alpha_{\mathrm{S} 1-1}$ casein (f24-199) decreased after $60 \mathrm{~d}$ of ripening in all cheeses. It was reported earlier that the relationship between the amounts of $\alpha_{\mathrm{S} 1}$-casein and $\alpha_{\mathrm{S} 1}-1$ peptides in cheese is very weak, probably

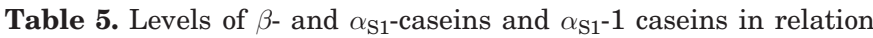
to the corresponding casein fraction at $\mathrm{d} 1$ of manufacture in full-fat and reduced-fat Cheddar cheeses during ripening. ${ }^{1}$

\begin{tabular}{|c|c|c|c|c|c|}
\hline \multirow[b]{2}{*}{ Treatment } & \multicolumn{5}{|c|}{ Ripening time, $\mathrm{d}$} \\
\hline & 1 & 30 & 60 & 120 & 180 \\
\hline \multicolumn{6}{|c|}{$\% \beta$-caseins $/ \beta$-caseins } \\
\hline FFC & 100 & $91.3^{\mathrm{ab}, \mathrm{A}}$ & $88.7^{\mathrm{a}, \mathrm{B}}$ & $87.8^{\mathrm{a}, \mathrm{C}}$ & $87.7^{\mathrm{a}, \mathrm{D}}$ \\
\hline RFC & 100 & $92.3^{\mathrm{ab}, \mathrm{A}}$ & $89.1^{\mathrm{a}, \mathrm{B}}$ & $87.9^{\mathrm{a}, \mathrm{C}}$ & $86.4^{\mathrm{a}, \mathrm{D}}$ \\
\hline RF-JFR1 & 100 & $83.1^{\mathrm{c}, \mathrm{A}}$ & $81.3^{\mathrm{c}, \mathrm{B}}$ & $77.1^{\mathrm{c}, \mathrm{C}}$ & $69.9^{\mathrm{d}, \mathrm{D}}$ \\
\hline RF-Slab & 100 & $88.7^{\mathrm{b}, \mathrm{A}}$ & $85.5^{\mathrm{b}, \mathrm{B}}$ & $82.9^{\mathrm{b}, \mathrm{C}}$ & $76.6^{\mathrm{c}, \mathrm{D}}$ \\
\hline RF-3534 & 100 & $91.6^{\mathrm{ab}, \mathrm{A}}$ & $89.9^{\mathrm{a}, \mathrm{B}}$ & $86.7^{\mathrm{a}, \mathrm{C}}$ & $83.4^{\mathrm{b}, \mathrm{D}}$ \\
\hline RF-5842 & 100 & $93.8^{\mathrm{a}, \mathrm{A}}$ & $89.5^{\mathrm{a}, \mathrm{B}}$ & $88.9^{\mathrm{a}, \mathrm{C}}$ & $87.6^{\mathrm{a}, \mathrm{D}}$ \\
\hline \multicolumn{6}{|c|}{$\% \alpha_{\mathrm{S} 1}$-caseins $/ \alpha_{\mathrm{S} 1}$-caseins } \\
\hline FFC & 100 & $63.0^{\mathrm{a}, \mathrm{A}}$ & $43.7^{\mathrm{a}, \mathrm{B}}$ & $31.2^{\mathrm{a}, \mathrm{C}}$ & $13.4^{\mathrm{a}, \mathrm{D}}$ \\
\hline $\mathrm{RFC}$ & 100 & $62.0^{\mathrm{a}, \mathrm{A}}$ & $45.9^{\mathrm{a}, \mathrm{B}}$ & $30.6^{\mathrm{a}, \mathrm{C}}$ & $12.7^{\mathrm{ab}, \mathrm{D}}$ \\
\hline RF-JFR1 & 100 & $51.6^{\mathrm{c}, \mathrm{A}}$ & $35.7^{\mathrm{c}, \mathrm{B}}$ & $18.0^{\mathrm{d}, \mathrm{C}}$ & $6.9^{\mathrm{d}, \mathrm{D}}$ \\
\hline RF-Slab & 100 & $57.8^{\mathrm{b}, \mathrm{A}}$ & $38.5^{\mathrm{b}, \mathrm{B}}$ & $22.8^{\mathrm{c}, \mathrm{C}}$ & $11.1^{\mathrm{c}, \mathrm{D}}$ \\
\hline RF-3534 & 100 & $62.6^{\mathrm{a}, \mathrm{A}}$ & $43.3^{\mathrm{a}, \mathrm{B}}$ & $28.6^{\mathrm{b}, \mathrm{C}}$ & $11.4^{\mathrm{bc}, \mathrm{D}}$ \\
\hline RF-5842 & 100 & $63.1^{\mathrm{a}, \mathrm{A}}$ & $45.9^{\mathrm{a}, \mathrm{B}}$ & $32.5^{\mathrm{a}, \mathrm{C}}$ & $13.6^{\mathrm{a}, \mathrm{D}}$ \\
\hline \multicolumn{6}{|c|}{$\% \alpha_{\mathrm{S} 1}-1$ caseins $/ \alpha_{\mathrm{S} 1^{-c a}}$} \\
\hline FFC & $18.0^{\mathrm{a}}$ & $47.3^{\mathrm{c}, \mathrm{B}}$ & $63.8^{\mathrm{b}, \mathrm{A}}$ & $61.0^{\mathrm{a}, \mathrm{A}}$ & $46.4^{\mathrm{b}, \mathrm{B}}$ \\
\hline $\mathrm{RFC}$ & $6.3^{\mathrm{c}}$ & $39.9^{\mathrm{d}, \mathrm{D}}$ & $58.5^{\mathrm{bc}, \mathrm{A}}$ & $53.8^{\mathrm{b}, \mathrm{B}}$ & $47.7^{\mathrm{b}, \mathrm{C}}$ \\
\hline RF-JFR1 & $11.0^{\mathrm{b}, \mathrm{E}}$ & $67.5^{\mathrm{a}, \mathrm{B}}$ & $72.7^{\mathrm{a}, \mathrm{A}}$ & $61.2^{\mathrm{a}, \mathrm{C}}$ & $38.5^{\mathrm{c}, \mathrm{D}}$ \\
\hline RF-Slab & $2.6^{\mathrm{d}, \mathrm{D}}$ & $33.8^{\mathrm{e}, \mathrm{C}}$ & $64.7^{\mathrm{b}, \mathrm{A}}$ & $64.0^{\mathrm{a}, \mathrm{A}}$ & $53.4^{\mathrm{a}, \mathrm{B}}$ \\
\hline RF-3534 & $2.9^{\mathrm{d}, \mathrm{D}}$ & $55.7^{\mathrm{b}, \mathrm{B}}$ & $59.0^{\mathrm{bc}, \mathrm{A}}$ & $53.7^{\mathrm{b}, \mathrm{B}}$ & $50.0^{\mathrm{b}, \mathrm{C}}$ \\
\hline RF-5842 & $15.7^{\mathrm{ab}, \mathrm{D}}$ & $43.6^{\mathrm{cd}, \mathrm{C}}$ & $57.1^{\mathrm{c}, \mathrm{A}}$ & $53.7^{\mathrm{b}, \mathrm{B}}$ & $43.1^{\mathrm{bc}, \mathrm{C}}$ \\
\hline
\end{tabular}

${ }^{\mathrm{a}-\mathrm{e}}$ Means within the same column with different subscriptions are significantly different $(P<0.05)$.

${ }^{\mathrm{A}-\mathrm{E}}$ Means within the same row with different subscriptions are significantly different $(P<0.05)$.

${ }^{1} \mathrm{FFC}=$ Full-fat control; RFC $=$ reduced-fat control; RF-JFR1 = reduced-fat cheese made with the ropy culture Lactococcus lactis ssp. cremoris JFR1; RF-Slab = reduced-fat cheese made with the capsuleforming nonropy strain Streptococcus thermophilus Slab; RF-3534 = reduced-fat cheese made with the moderate ropy strain Streptococcus thermophilus CHCC 3534; and RF-5842 = reduced-fat cheese made with the exopolysaccharide-negative genetic variant Streptococcus thermophilus CHCC 5842.

because $\alpha_{\mathrm{S} 1}$-casein can be hydrolyzed to other products of low molecular weight (less than $11 \mathrm{kD}$; Marcos et al., 1979). In addition, $\alpha_{\mathrm{S} 1}-1$ casein undergoes further degradation by rennet or other proteases (Grappin et al., 1985).

\section{Changes in Peptide Profile During Cheese Ripening}

The reverse phase-HPLC chromatograms of watersoluble peptides from cheeses during ripening are shown in Figure 2, panels A to F. The chromatograms were divided into 6 zones (I, II, III, IV, V, and VI), each of which contained one peak or more. Similar to previous findings for Cheddar cheese (Fenelon et al., 2000), the chromatograms for all cheeses showed agerelated changes in the area and distribution of different peaks. This trend is consistent with the increase in WSN in all cheeses and suggests the progressive breakdown of casein by residual coagulant, plasmin, and microbial proteinases, resulting in the formation of peptides of different molecular masses and free amino 
$\mathbf{A}$
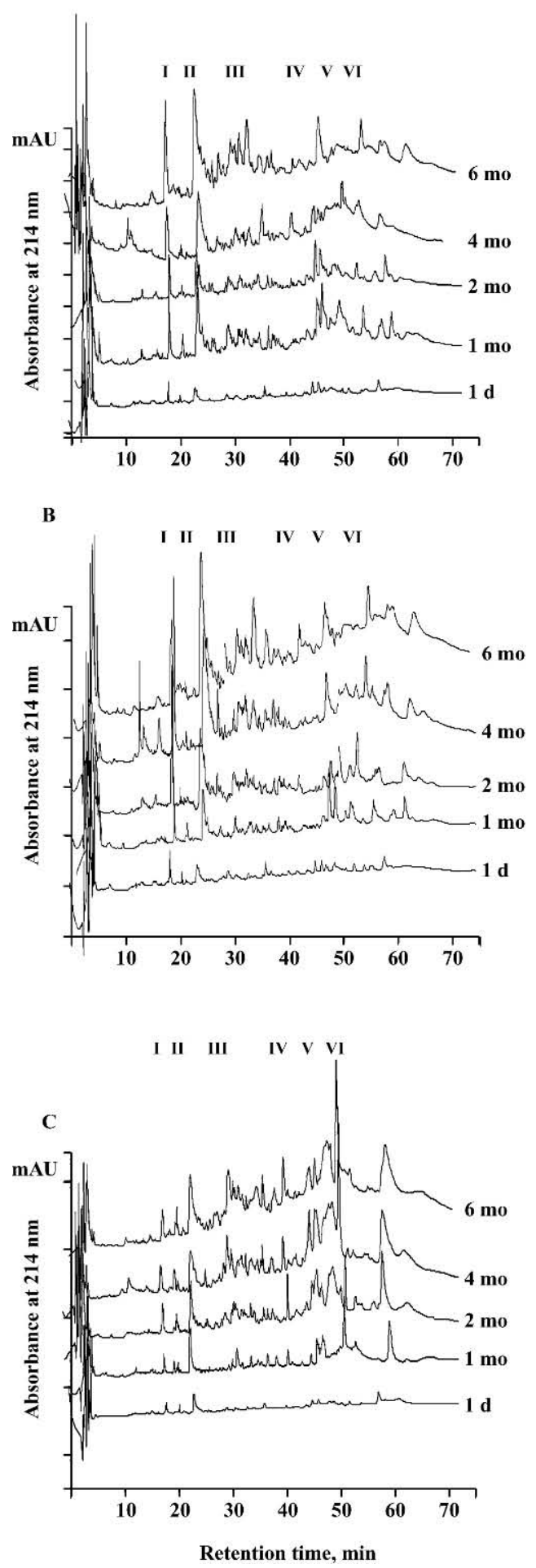

D
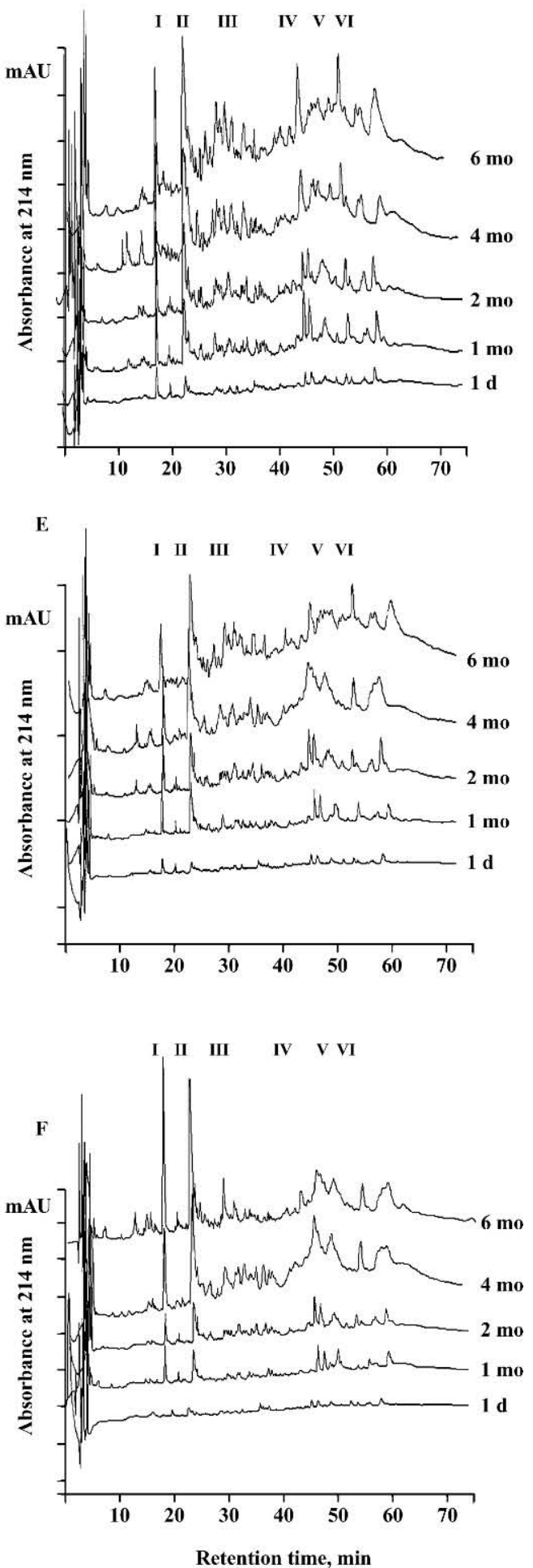

Figure 2. Reverse phase-HPLC chromatograms of water-soluble nitrogen (WSN) extract from A) FFC (full-fat control), B) RFC (reducedfat control), C) RF-JFR1 (reduced-fat Cheddar cheese made with ropy Lactococcus lactis spp cremoris JFR1), D) RF-Slab (reduced-fat Cheddar cheese made with capsule-forming nonropy Streptococcus thermophilus Slab, E) RF-3534 (reduced-fat Cheddar cheese made with the exopolysaccharide (EPS)-producing moderate ropy Streptococcus thermophilus CHCC 3534), and F) RF-5842 (reduced-fat Cheddar cheese made EPS-nonproducing culture Streptococcus thermophilus CH 5842) at 0 (1 d), 1, 2, 4, and 6 mo of ripening. The chromatograms were compiled from the mean data taken from 3 replicate trials. 
acids. The total peaks area, and in particular, that of the early eluting peaks increased during storage. The late eluting peaks increased during the first 4 mo of ripening and decreased thereafter. The results indicated the accumulation of new proteolytic products and increasing contribution of bacterial enzymes with ripening time.

Major differences were found between the peptide profiles of the WSN of RF-JFR1 (which contained the highest moisture and chymosin activity levels) and those from all other cheeses. Peaks I and II were present at relatively low concentrations in RF-JFR1 (Figure $2 \mathrm{C}$ ), suggesting that peptides corresponding to these peaks were produced by proteinases from commercial culture used in all cheeses but RF-JFR1. The retention times of peaks I and II were very similar to those of $\alpha_{\mathrm{S} 1}$-casein (f 1-9) and $\alpha_{\mathrm{S} 1}$-casein (f 1-13) produced in Cheddar cheese by proteinases from Lactococcus (Singh et al., 1994).

At all stages of storage, the reverse phase-HPLC profile for the WSN of RF-JFR1 differed markedly from those of all other cheeses. The WSN of RF-JFR1 showed the greatest number and widest distribution of lateeluting peaks (retention time $>45 \mathrm{~min}$ ), denoted collectively as zones IV, V, and VI. Such peaks correspond to high molecular weight and hydrophobic peptides (Lemieux and Simard, 1992). The larger area of lateeluting peaks in RF-JFR1 (Figure 2C) might indicate accumulation of peptides produced by rennet (as indicated by the high level of WSN found in this cheese), which were not degraded further to peptides of lower hydrophobicity and molecular mass, due to the absence or weak starter culture peptidases (Lemieux and Simard, 1992; Awad et al., 2000). At the same time, the WSN of RF-JFR1 showed a lower concentration of earlyeluting peaks, especially the peak with retention time of $18 \mathrm{~min}$, denoted collectively as zone I. The total peak area in zones I and II increased during storage in all cheeses except RF-JFR1, which contained the lowest ratio of hydrophilic to hydrophobic peptides (Table 6). The WSN of RF-Slab (Figure 2D) showed a high number and wide distribution of the early and middle-eluting peaks (retention time $<35 \mathrm{~min}$ ), which probably correspond to low molecular weight and hydrophilic peptides (Lemieux and Simard, 1992). The total area of lateeluting peaks (zones V and VI) and the ratio of hydrophobic to hydrophilic peptides were generally smaller in RF-Slab than in all other reduced-fat cheeses made with EPS-producing cultures after $60 \mathrm{~d}$ of ripening (Table 6). Cheese RF-JFR1 contained the highest levels of the late-eluting peptides and lowest ratio of hydrophilic to hydrophobic peptides among all cheeses. Bitter peptides are rich in hydrophobic amino acids residues (Lemieux and Simard, 1992) and exhibit
Table 6. Ratio of hydrophilic to hydrophobic peptides separated by reverse phase-HPLC and percentage of hydrophobic peptides of total peptides in full-fat and reduced-fat Cheddar cheeses during ripening.

\begin{tabular}{lccccc}
\hline & \multicolumn{5}{c}{ Ripening time, $\mathrm{d}$} \\
\cline { 2 - 6 } Treatment & 1 & 30 & 60 & 120 & 180 \\
\hline \multicolumn{5}{c}{ Ratio of hydrophilic to hydrophobic peptides } \\
FFC & $1.9^{\mathrm{a}, \mathrm{A}}$ & $0.8^{\mathrm{b}, \mathrm{D}}$ & $1.2^{\mathrm{a}, \mathrm{C}}$ & $1.5^{\mathrm{a}, \mathrm{B}}$ & $1.9^{\mathrm{ab}, \mathrm{A}}$ \\
RFC & $1.4^{\mathrm{b}, \mathrm{B}}$ & $1.0^{\mathrm{ab}, \mathrm{C}}$ & $1.1^{\mathrm{b}, \mathrm{C}}$ & $1.3^{\mathrm{b}, \mathrm{B}}$ & $1.8^{\mathrm{b}, \mathrm{A}}$ \\
RF-JFR1 & $1.2^{\mathrm{c}, \mathrm{A}}$ & $0.5^{\mathrm{c}, \mathrm{B}}$ & $0.5^{\mathrm{d}, \mathrm{B}}$ & $0.4^{\mathrm{d}, \mathrm{C}}$ & $0.5^{\mathrm{d}, \mathrm{B}}$ \\
RF-Slab1 & $1.2^{\mathrm{c}, \mathrm{C}}$ & $1.2^{\mathrm{a}, \mathrm{C}}$ & $0.8^{\mathrm{c}, \mathrm{D}}$ & $1.5^{\mathrm{a}, \mathrm{B}}$ & $2.0^{\mathrm{a}, \mathrm{A}}$ \\
RF-3534 & $1.0^{\mathrm{c}, \mathrm{B}}$ & $1.2^{\mathrm{a}, \mathrm{A}}$ & $0.8^{\mathrm{c}, \mathrm{C}}$ & $1.0^{\mathrm{c}, \mathrm{B}}$ & $0.9^{\mathrm{c}, \mathrm{C}}$ \\
RF-5842 & $1.3^{\mathrm{bc}, \mathrm{A}}$ & $1.3^{\mathrm{a}, \mathrm{A}}$ & $0.8^{\mathrm{c}, \mathrm{C}}$ & $1.0^{\mathrm{c}, \mathrm{B}}$ & $1.0^{\mathrm{c}, \mathrm{B}}$ \\
\% Hydrophobic peptides & of total peptides & & \\
FFC & $34.3^{\mathrm{d}, \mathrm{D}}$ & $55.6^{\mathrm{b}, \mathrm{A}}$ & $44.5^{\mathrm{c}, \mathrm{B}}$ & $40.7^{\mathrm{c}, \mathrm{C}}$ & $34.4^{\mathrm{c}, \mathrm{D}}$ \\
RFC & $41.8^{\mathrm{c}, \mathrm{B}}$ & $50.8^{\mathrm{b}, \mathrm{A}}$ & $47.9^{\mathrm{c}, \mathrm{A}}$ & $44.3^{\mathrm{c}, \mathrm{B}}$ & $36.0^{\mathrm{c}, \mathrm{C}}$ \\
RF-JFR1 & $45.8^{\mathrm{b}, \mathrm{C}}$ & $65.7^{\mathrm{a}, \mathrm{B}}$ & $68.5^{\mathrm{a}, \mathrm{B}}$ & $72.7^{\mathrm{a}, \mathrm{A}}$ & $67.3^{\mathrm{a}, \mathrm{B}}$ \\
RF-Slab & $46.5^{\mathrm{ab}, \mathrm{B}}$ & $45.1^{\mathrm{c}, \mathrm{B}}$ & $55.3^{\mathrm{b}, \mathrm{A}}$ & $39.6^{\mathrm{c}, \mathrm{C}}$ & $33.2^{\mathrm{c}, \mathrm{D}}$ \\
RF-3534 & $48.9^{\mathrm{a}, \mathrm{B}}$ & $44.7^{\mathrm{c}, \mathrm{C}}$ & $56.0^{\mathrm{b}, \mathrm{A}}$ & $50.7^{\mathrm{b}, \mathrm{AB}}$ & $53.4^{\mathrm{b}, \mathrm{A}}$ \\
RF-5842 & $44.3^{\mathrm{bc}, \mathrm{C}}$ & $43.7^{\mathrm{d}, \mathrm{C}}$ & $56.1^{\mathrm{b}, \mathrm{A}}$ & $51.1^{\mathrm{b}, \mathrm{B}}$ & $51.3^{\mathrm{b}, \mathrm{B}}$ \\
\hline
\end{tabular}

${ }^{\mathrm{a}-\mathrm{d}}$ Means within the same column with different subscriptions are significantly different $(P<0.05)$

${ }^{\mathrm{A}-\mathrm{D}}$ Means within the same row with different subscriptions are significantly different $(P<0.05)$.

${ }^{1} \mathrm{FFC}=$ Full-fat control; RFC = reduced-fat control; RF-JFR $1=$ reduced-fat cheese made with the ropy culture Lactococcus lactis ssp. cremoris JFR1; RF-Slab = reduced-fat cheese made with the capsuleforming nonropy strain Streptococcus thermophilus Slab; RF-3534 = reduced-fat cheese made with the moderate ropy strain Streptococcus thermophilus CHCC 3534; and RF-5842 = reduced-fat cheese made with the exopolysaccharide-negative genetic variant Streptococcus thermophilus CHCC 5842.

higher retention times on reverse phase-HPLC columns (Cliffe and Law, 1990; Awad et al., 1999). In contrast, Lee and Warthesen (1996) found little correlation between retention time on the reverse phase-HPLC column and peptide hydrophobicity or suspected bitterness. The high residual chymosin activity and moisture content and low salt-in-moisture in RF-JFR1 might have increased the level of the hydrophobic peptides. Cell envelope proteinases from JFR1 could have accumulated bitter peptides (Broadbent et al., 2002).

\section{CONCLUSIONS}

A ropy strain of Lactococcus lactis ssp. cremoris that produced reduced-fat cheese with similar textural characteristics to its full-fat counterpart accumulated high levels of hydrophobic (bitter) peptides. The high level of such peptides was associated with high MNFS and chymosin activity. However, an adjunct culture of capsule-forming nonropy $S$. thermophilus increased the moisture level of reduced-fat cheese without producing high levels of bitter peptides because of its ability to hydrolyze them. This study shows that increasing MNFS in reduced-fat Cheddar cheese to levels similar to those in the full-fat counterpart might result in bitterness due to the increased chymosin activity and 
lower salt-in-moisture levels. To produce reduced-fat Cheddar cheese with characteristics similar to those of its full-fat counterpart using EPS-producing cultures, debittering strains and reduction of residual chymosin activity should be considered.

\section{ACKNOWLEDGMENTS}

This work was supported in part by the MinnesotaSouth Dakota Dairy Foods Research Center.

\section{REFERENCES}

Adapa, S., and K. A. Schmidt. 1998. Physical properties of low-fat sour cream containing exopolysaccharide-producing lactic acid. J. Food Sci. 63:901-903.

Andrews, A. T. 1983. Proteinases in normal bovine milk and their action on caseins. J. Dairy Res. 50:45-55.

Association of Official Analytical Chemists. 2003. Official Methods of Analysis. 17th ed. AOAC, Gaithersburg, MD.

Awad, S., A. Hassan, and K. Muthukumarappan. 2005. Application of exopolysaccharide-producing cultures in reduced fat Cheddar cheese. Texture and melting properties. J. Dairy Sci. 88:42044213.

Awad, S., Q. Luthi-Peng, and Z. Puhan. 1999. Influence of coagulants and starter bacteria on proteolysis and sensory quality of Gouda type cheese from buffalo milk. Sci. Tecn. Latt. Cas. 50:405-430.

Awad, S., Q. Luthi-Peng, and Z. Puhan. 2000. Proteolytic activity of starter bacteria on buffalo casein peptides produced by coagulants of different origins. Milchwissenschaft 55:492-495.

Berg, G. V., and F. A. Exterkate. 1993. Technological parameters involved in cheese ripening. Int. Dairy J. 3:485-507.

Broadbent, J. R., M. Barnes, C. Brennand, M. Strickland, K. Houck, M. Johnson, and J. Steele. 2002. Contribution of Lactococcus lactis cell envelope proteinase specificity to peptide accumulation and bitterness in reduced-fat Cheddar cheese. Appl. Environ. Microbiol. 68:1778-1785.

Broadbent, J. R., D. J. McMahon, D. L. Welker, C. J. Oberg, and S. Moineau. 2003. Biochemistry, genetics, and applications of exopolysaccharide production in Streptococcus thermophilus: A review. J. Dairy Sci. 86:407-423.

Broadbent, J. R., M. Strickland, B. Weimer, M. E. Johnson, and J. L. Steele. 1998. Peptide accumulation and bitterness in Cheddar cheese made using single-strain Lactococcus lactis starters with distinct proteinase specificities. J. Dairy Sci. 81:327-337.

Cliffe, A. J., and B. A. Law. 1990. Peptide composition of enzymetreated Cheddar cheese slurries, determined by reverse phase high performance liquid chromatography. Food Chem. 36:73-80.

Dabour, N., E. E. Kheadr, I. Fliss, and G. LaPointe. 2005. Impact of ropy and capsular exopolysaccharide-producing strains of Lactococcus lactis subsp. cremoris on reduced-fat Cheddar cheese production and whey composition. Int. Dairy J. 15:459-471.

Fenelon, M. A., and T. P. Guinee. 1999. The effect of milk fat on Cheddar cheese yield and its prediction, using modifications of the Van Slyke cheese yield formula. J. Dairy Sci. 82:2287-2299.

Fenelon, M. A., P. O'Connor, and T. P. Guinee. 2000. The effect of fat content on the microbiology and proteolysis in Cheddar cheese during ripening. J. Dairy Sci. 83:2173-2183.

Folkertsma, B., and P. F. Fox. 1992. Use of the cadmium-ninhydrin reagent to assess proteolysis in cheese during ripening. J. Dairy Res. 59:217-224.

Fox, P. F., and P. L. H. McSweeney. 1996. Proteolysis in cheese during ripening. Food Rev. Int. 12:457-509.
Grappin, R., T. C. Rank, and N. F. Olson. 1985. Primary proteolysis of cheese proteins during ripening: A review. J. Dairy Sci. 68:531-540.

Guinee, T. P., M. A. E. Auty, and M. A. Fenelon. 2000. The effect of fat content on the rheology, microstructure and heat-induced functional characteristics of Cheddar cheese. Int. Dairy J. 10:277-288.

Hassan, A. N., M. Corredig, J. Frank, and M. El-Soda. 2004. Microstructure and rheology of an acid-coagulated cheese (Karish) made with an exopolysaccharide-producing Streptococcus thermophilus strain and its exopolysaccharide non-producing genetic variant. J. Dairy Res. 71:116-120.

Hassan, A. N., J. F. Frank, and M. El-Soda. 2003. Observation of bacterial exopolysaccharide in dairy products using cryo-scanning electron microscopy. Int. Dairy J. 13:755-762.

Hassan, A. N., J. F. Frank, M. A. Farmer, K. A. Schmidt, and S. I. Shalabi. 1995. Observation of encapsulated lactic acid bacteria using confocal scanning laser microscopy. J. Dairy Sci. 78:2624-2628.

Hassan, A. N., J. F. Frank, K. A. Schmidt, and S. I. Shalabi. 1996. Rheological properties of yogurt made with encapsulated nonropy lactic cultures. J. Dairy Sci. 79:2091-2097.

Hurley, M. J., B. M. O'Driscoll, A. L. Kelly, and P. L. H. McSweeney. 1999. Novel assay for determination of residual coagulant activity in cheese. Int. Dairy J. 9:553-558.

Kuchroo, C. N., and P. F. Fox. 1982. Soluble nitrogen in Cheddar cheese. Comparison of extraction procedures. Milchwissenschaft 37:331-335.

Lee, K. D., and J. J. Warthesen. 1996. Mobile phases in reversephase HPLC for the determination of bitter peptides in cheese. J. Food Sci. 61:291-294.

Lemieux, L., and R. E. Simard. 1992. Bitter flavor in dairy products. II. A review of bitter peptides from casein: Their formation, isolation and identification, structure masking and inhibition. Lait 72:335-382.

Marcos, A., M. A. Esteban, F. Leon, and J. Fernandez-Salguero. 1979. Electrophoretic patterns of European cheeses: Comparison and quantitation. J. Dairy Sci. 62:892-900.

Midje, L. D., E. D. Bastian, H. A. Morris, F. B. Martin, T. Bridgeman, and Z. M. Vickers. 2000. Flavour enhancement of reduced fat Cheddar cheese using an integrated culturing system. J. Agric. Food Chem. 48:1630-1636.

Mistry, V. V. 2001. Low fat cheese technology. Int. Dairy J. 11:413-422.

Mistry, V. V., and K. M. Kasperson. 1998. Influence of salt on quality of reduced fat cheddar cheese. J. Dairy Sci. 81:1214-1221.

Perry, D. B., D. J. McMahon, and C. J. Oberg. 1998. Manufacture of low fat Mozzarella cheese using exopolysaccharide-producing starter cultures. J. Dairy Sci. 81:563-566.

Sallami, L., E. E. Kheadr, I. Fliss, and C. J. Vuillemard. 2004. Impact of autolytic, proteolytic, and nisin-producing adjunct cultures on biochemical and textural properties of Cheddar cheese. J. Dairy Sci. 87:1585-1594.

SAS Institute. 1999. SAS User's Guide. Statistics, Version 8 edition. SAS Inst., Inc., Cary, NC.

Singh, T. K., M. A. Drake, and K. R. Cadwallader. 2003. Flavor of Cheddar cheese: A chemical and sensory perspective. Comp. Rev. Food Sci. Food Safety 2:139-162.

Singh, T. K., P. F. Fox, P. Hojrup, and A. Heals. 1994. A scheme for the fractionation of cheese nitrogen and identification of principal peptides. Int. Dairy J. 4:111-122.

Visser, F. M. W. 1977. Contribution of enzymes from rennet, starter bacteria and milk to proteolysis and flavour development in Gouda cheese. 1. Description of cheese and aseptic cheese-making techniques. Neth. Milk Dairy J. 31:120-133.

Visser, S. 1993. Proteolytic enzymes and their relation to cheese ripening and flavor: An overview. J. Dairy Sci. 76:329-350. 